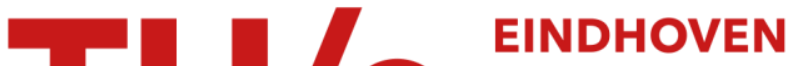 UNIVERSITY OF TECHNOLOGY
}

\section{Atomic layer deposition of highly dispersed Pt nanoparticles on a high surface area electrode backbone for electrochemical promotion of catalysis}

\author{
Citation for published version (APA): \\ Hajar, Y., Di Palma, V., Kyriakou, V., Verheijen, M. A., Baranova, E. A., Vernoux, P., Kessels, W. M. M., \\ Creatore, M., van de Sanden, M. C. M., \& Tsampas, M. (2017). Atomic layer deposition of highly dispersed Pt \\ nanoparticles on a high surface area electrode backbone for electrochemical promotion of catalysis. \\ Electrochemistry Communications, 84, 40-44. https://doi.org/10.1016/j.elecom.2017.09.023
}

\section{Document license: \\ TAVERNE}

DOI:

10.1016/j.elecom.2017.09.023

Document status and date:

Published: 01/11/2017

\section{Document Version:}

Publisher's PDF, also known as Version of Record (includes final page, issue and volume numbers)

\section{Please check the document version of this publication:}

- A submitted manuscript is the version of the article upon submission and before peer-review. There can be important differences between the submitted version and the official published version of record. People interested in the research are advised to contact the author for the final version of the publication, or visit the DOI to the publisher's website.

- The final author version and the galley proof are versions of the publication after peer review.

- The final published version features the final layout of the paper including the volume, issue and page numbers.

Link to publication

\footnotetext{
General rights

- You may freely distribute the URL identifying the publication in the public portal. follow below link for the End User Agreement:

www.tue.nl/taverne

\section{Take down policy}

If you believe that this document breaches copyright please contact us at:

openaccess@tue.nl

providing details and we will investigate your claim.
}

Copyright and moral rights for the publications made accessible in the public portal are retained by the authors and/or other copyright owners and it is a condition of accessing publications that users recognise and abide by the legal requirements associated with these rights.

- Users may download and print one copy of any publication from the public portal for the purpose of private study or research.

- You may not further distribute the material or use it for any profit-making activity or commercial gain

If the publication is distributed under the terms of Article $25 \mathrm{fa}$ of the Dutch Copyright Act, indicated by the "Taverne" license above, please 


\title{
Atomic layer deposition of highly dispersed Pt nanoparticles on a high surface area electrode backbone for electrochemical promotion of catalysis
}

\author{
Y. Hajar ${ }^{\mathrm{a}, 1}$, V. Di Palma ${ }^{\mathrm{b}, 1}$, V. Kyriakou ${ }^{\mathrm{c}}$, M.A. Verheijen ${ }^{\mathrm{b}}$, E.A. Baranova ${ }^{\mathrm{a}, \mathrm{d}}$, P. Vernoux ${ }^{\mathrm{d}}$, \\ W.M.M. Kessels ${ }^{\mathrm{b}}$, M. Creatore ${ }^{\mathrm{b}}$, M.C.M. van de Sanden ${ }^{\mathrm{b}, \mathrm{c}}$, M.N. Tsampas ${ }^{\mathrm{c}, *}$ \\ a Department of Chemical and Biological Engineering, Centre for Catalysis Research and Innovation, University of Ottawa,161 Louis-Pasteur, Ottawa, ON K1N 6N5, \\ Canada \\ ${ }^{\mathrm{b}}$ Department of Applied Physics, Eindhoven University of Technology, 5600 MB Eindhoven, The Netherlands \\ ${ }^{c}$ Dutch Institute For Fundamental Energy Research (DIFFER), 5612 AJ Eindhoven, The Netherlands \\ ${ }^{\mathrm{d}}$ Université de Lyon, Institut de Recherches sur la Catalyse et l'Environnement de Lyon, UMR 5256, CNRS, Université Claude Bernard Lyon 1, 2 avenue A. Einstein, 69626 \\ Villeurbanne, France
}

\section{A R T I C L E I N F O}

\section{Keywords:}

Electrochemical promotion of catalysis

Atomic layer deposition

Pt-nanoparticles

LSM/GDC composite electrode

Propane oxidation

\begin{abstract}
A B S T R A C T
A novel catalyst design for electrochemical promotion of catalysis (EPOC) is proposed which overcomes the main bottlenecks that limit EPOC commercialization, i.e., the low dispersion and small surface area of metal catalysts. We have increased the surface area by using a porous composite electrode backbone made of $\left(\mathrm{La}_{0.8} \mathrm{Sr}_{0.2}\right)_{0.95} \mathrm{MnO}_{3-\delta} / \mathrm{Ce}_{0.9} \mathrm{Gd}_{0.1} \mathrm{O}_{1.95}$ (LSM/GDC). Highly dispersed Pt nanoparticles with an average diameter of $6.5 \mathrm{~nm}$ have been deposited on LSM/GDC by atomic layer deposition (ALD). This novel design offers, for the first time, a controllable and reproducible method for the fabrication of EPOC catalysts. The bare electrode backbone shows negligible activity for propane oxidation, while in the presence of Pt nanoparticles a high catalytic activity is obtained above $200{ }^{\circ} \mathrm{C}$. The performance of the Pt-loaded LSM/GDC catalyst was significantly improved by application of small currents $(I<500 \mu \mathrm{A})$, leading to a 27-33\% increase as a function of the open circuit catalytic rate, with apparent Faradaic efficiency values ranging from 1000 to $3860 \%$ at $300{ }^{\circ} \mathrm{C}$. Our results demonstrate that EPOC is a valid approach for enhancing the catalytic activity of nano-structured catalysts.
\end{abstract}

\section{Introduction}

The approach known as electrochemical promotion of catalysis (EPOC) refers to the pronounced reversible and controlled changes in catalytic properties (activity and selectivity) that occur upon electrical polarization [1-4]. Since the discovery of the effect [5], > 100 different catalytic systems have been electrochemically promoted on various metal catalysts supported on different ionic conductors [1-6].

EPOC studies employ an electrochemical cell in which one of the electrodes is the catalyst for the reaction under study. By controlling the polarization, ions can be pumped towards or away from the catalyst, changing its work function and thus its catalytic properties [1-6]. Despite the apparent advantages of this system, such as controlling the coverage of the promoting ions in situ, EPOC has not yet had any industrial applications, mainly due to its much lower activity per catalytic mass compared with classic nano-dispersed powders [2,7-12]. Therefore, in the last few years, EPOC research has been focused on overcoming this issue, which would help advance the scaling up of the concept [2,7-17].

The most promising EPOC catalyst design has been reported by Kambolis et al., in which Pt nanoparticles have been deposited by wet impregnation into a porous LSCF/GDC $\left(\mathrm{La}_{0.6} \mathrm{Sr}_{0.4} \mathrm{Co}_{0.2} \mathrm{Fe}_{0.8} \mathrm{O}_{3-\delta} /\right.$ $\mathrm{Ce}_{0.9} \mathrm{Gd}_{0.1} \mathrm{O}_{1.95}$ ) electrode [10]. This design was inspired by solid oxide electrolyte cells (SOEC) [18], with the porous nature of LSCF/GDC offering a higher surface area than conventional pure metallic films. In addition, LSCF mainly plays the role of an electron conductor while GDC is an ionic conductor [19], so the combination provides the two functionalities that are important for electrocatalysis [1-4]. The aforementioned approach resulted in highly dispersed Pt nanoparticles of 3-20 nm with an average size of $8 \mathrm{~nm}$. However, wet impregnation constitutes a poor technique in terms of reproducibility and control of the particle load and its size distribution. In this study we propose a more reliable method, i.e. atomic layer deposition (ALD), aimed at overcoming the limitations outlined above.

\footnotetext{
* Corresponding author.

E-mail address: m.tsampas@differ.nl (M.N. Tsampas).

${ }^{1}$ First and second authors have contributed equally and possess the first authorship of this article.
} 
ALD is a thin film deposition technique based on the chemical reaction of gas phase species on a solid surface. ALD is currently used commercially by the semiconductor industry and thin-film magnetic head industry. There has also been recent interest in using ALD in other application areas, such as photovoltaics and organic electronics. ALD is performed by the sequential exposure of the substrate to two (or more) different gas species separated in time by purging steps. Each gas species reacts with the substrate up to saturation, through a self-limiting reaction mechanism. Because of its self-limiting nature, the main advantages of ALD are the control of film thickness at the atomic scale, high conformity with surface features and high reproducibility [20-26]. On most metal oxides, ALD generally starts with the growth of small islands (i.e. nanoparticles) and many ALD cycles are required to obtain a completely closed film. Therefore, ALD is ideal for accessing and decorating the entire volume of our porous electrode backbone with $\mathrm{Pt}$ nanoparticles.

The aim of this study is to investigate the electro-promotion of propane oxidation over highly dispersed Pt nanoparticles prepared by ALD. The electrode backbone in which Pt nanoparticles are deposited is a porous $\left(\mathrm{La}_{0.8} \mathrm{Sr}_{0.2}\right)_{0.95} \mathrm{MnO}_{3-\delta} / \mathrm{Ce}_{0.9} \mathrm{Gd}_{0.1} \mathrm{O}_{1.95}$ (LSM/GDC) composite, which offers mixed ionic-electronic conductivity. $100 \mathrm{Pt}$ ALD cycles were selected based on literature studies of Pt deposition on flat $\mathrm{Al}_{2} \mathrm{O}_{3}$ substrates in which 100 cycles resulted in Pt nanoparticles with an average size of $4.5 \mathrm{~nm}$ [22].

\section{Experimental}

\subsection{Cell preparation and characterization}

Two commercial partial cells (FuelCellMaterials) with a $50 \mu \mathrm{m}$ LSM/GDC composite electrode (50\%-50\%, $17 \mathrm{~mm}$ diameter) deposited on a $150 \mu \mathrm{m}$ Hionic $^{\mathrm{TM}}$ electrolyte support $(20 \mathrm{~mm}$ diameter) were employed in the present study. One was used as a reference cell, while the second was dedicated to the Pt ALD case study.

Two gold films were deposited on the opposite side of the Hionic ${ }^{\mathrm{TM}}$ pellet, to act as counter and reference electrodes, respectively. Gold was selected due to its negligible catalytic activity in propane oxidation, as verified through blank experiments under experimental conditions. An electrochemical workstation Voltalab PGP 201 (Radiometer) was used to apply and measure both potential and current. The catalyst potential $\Delta U_{\mathrm{WR}}$ was measured between the working electrode (Pt-LSM/GDC) and the reference electrode $(\mathrm{Au})$.

Pt was deposited on the porous LSM/GDC by ALD using a homemade deposition system described in detail elsewhere [24]. The base pressure of the reactor was $<10^{-6}$ mbar. $\mathrm{MeCpPtMe}_{3}$ (98\% from Sigma Aldrich) was used as precursor and $\mathrm{O}_{2}$ gas at 1 mbar as reactant. The precursor was contained in a stainless steel cylinder, heated at $30{ }^{\circ} \mathrm{C}$, and brought into the reactor using Ar as carrier gas. The lines from the precursor to the reactor were heated to $50{ }^{\circ} \mathrm{C}$ and the reactor wall to $90{ }^{\circ} \mathrm{C}$. The ALD recipe starts by dosing $\mathrm{MeCpPtMe}_{3}$ for $4 \mathrm{~s}$, then using $3 \mathrm{~s}$ of Ar to purge the precursor line, followed by $3 \mathrm{~s}$ of pumping down. Then $\mathrm{O}_{2}$ gas is dosed for $10 \mathrm{~s}$ and afterwards the reactor is pumped down for $10 \mathrm{~s}$. The deposition was carried out with the substrate holder maintained at $300^{\circ} \mathrm{C}$. The ideal procedure for Pt ALD deposition on LSM/GDC is shown in Fig. 1(a).

\subsection{SEM and TEM microscopy}

A cross-sectional sample for transmission electron microscopy (TEM) analysis was made by means of standard focus ion beam (FIB) lift-out sample preparation and SEM images by an FEI Nova 600 Nanolab SEM/FIB. Prior to FIB milling, a stack of protective layers consisting of $\mathrm{SiO}_{2}$ and Pt was deposited in the FIB. Subsequent TEM studies were performed using a JEOL ARM 200 probe corrected TEM, operated at $200 \mathrm{kV}$, equipped with a $100 \mathrm{~mm}^{2}$ Centurio SDD EDS detector.

\subsection{Catalytic activity measurements}

The design of the experimental setup has been described in detail elsewhere $[6,13]$. The reactant gases were certified mixtures of 0.80 , 5.0 and $99.999 \% \mathrm{C}_{3} \mathrm{H}_{8}, \mathrm{O}_{2}$ and $\mathrm{He}$ (Air Liquide), respectively. The analysis of reactants and products was carried out by online gas-chromatography (R3000 micro-GC SRA instruments) and IR spectroscopy (Horiba VA3000).

Under closed circuit conditions, the cell-reactor could operate as an electrochemical oxygen "pump". Using an external power source, a current, $I$, can be imposed through the oxygen-ion $\left(\mathrm{O}^{2-}\right)$ conducting solid electrolyte, which corresponds to an oxygen-ion flux of $\mathrm{I} / 2 F$. In order to quantify the EPOC, Vayenas and co-workers [1] have defined two dimensionless parameters, apparent Faradaic efficiency, $\Lambda$, and rate enhancement ratio, $\rho$, as follows:

$\Lambda=(r-r o) /(I / n F)$

$\rho=r / r_{0}$

where $r$ is the closed-circuit reaction rate (i.e. under polarization) and $r_{\mathrm{o}}$ is the open-circuit reaction rate (i.e. at $I=0$ ) and $I / n F$ is the imposed flux of $\mathrm{O}^{2-}$, where $n$ is the number of exchanged electrons.

\section{Results and discussion}

Analysis of the Pt nanoparticles deposited on the porous LSM/GDC is not a trivial task. In our previous work [10] we employed an extractive replica technique for TEM analysis of the Pt nanoparticles, which involves electrode crushing and the dissolution of the electrode backbone in a hydrofluoric acid solution. In order to gain further insight into the distribution of Pt on the electrode backbone, we conducted a TEM analysis on a cross-section of an electrode (after catalysis). Fig. 1(b,c) shows SEM images of the electrode surface before and during FIB preparation of the TEM lamella.

A High Angle Annular Dark Field (HAADF)-scanning TEM image of the entire TEM lamella is displayed in Fig. 1(d). In this sample three sites of interest have been denoted as P1, P2 and P3. TEM images of these areas are shown in Fig. 1(e-g). The presence and distribution of the Pt particles can be clearly discerned. Because of the different inclinations of the grain surfaces with respect to the imaging direction, both vertical and lateral dimensions of the Pt particles can be imaged.

ImageJ software was used to determine the Pt particle size distributions, which for areas P1 and P2 are presented in Fig. 1(h,i) and for the entire lamella area in Fig. 1(j). The Pt nanoparticles have a uniform distribution with a particle size range of 3-10 $\mathrm{nm}$ and an average size of $6.5 \mathrm{~nm}$. Considering hemi-spherical Pt nanoparticles, one can estimate a Pt dispersion of $18.2 \%$ [27]. Particle size analysis was performed after catalytic evaluation. It is well known that the particle size might increase after catalysis due to agglomeration [28] Moreover, the growth of the nanoparticles is influenced by the substrate [22]. Taking this into account, the average Pt particle size of $6.5 \mathrm{~nm}$ after 100 ALD cycles is not too far from the reported value of $4.5 \mathrm{~nm}$ on $\mathrm{Al}_{2} \mathrm{O}_{3}$ [22].

In order to evaluate the catalytic performance of the Pt nanoparticles deposited on the LSM/GDC support, light-off experiments were performed on both the Pt-LSM/GDC (without involving a pre-reduction step for Pt) and bare LSM/GDC samples (Fig. 2(a)). The temperature was increased from ambient to $425^{\circ} \mathrm{C}$ with a heating rate of $2{ }^{\circ} \mathrm{C} /$ min. Fig. 2(a) shows the $\mathrm{CO}_{2}$ production rate and the $\mathrm{C}_{3} \mathrm{H}_{8}$ conversion as a function of temperature. It can be seen that the LSM/GDC support was totally inactive for propane oxidation, while the addition of the Pt nanoparticles strongly increased the catalytic activity. For the Pt-loaded sample, the conversion of propane was shown to increase rapidly after $200{ }^{\circ} \mathrm{C}$ and reach $23 \%$ at $425^{\circ} \mathrm{C}$.

The impact of various polarizations between $-1.0 \mathrm{~V}$ and $+1.0 \mathrm{~V}$ on the catalytic performance of the Pt-free LSM/GDC sample was investigated at $300{ }^{\circ} \mathrm{C}$, and no modification of the propane conversion 


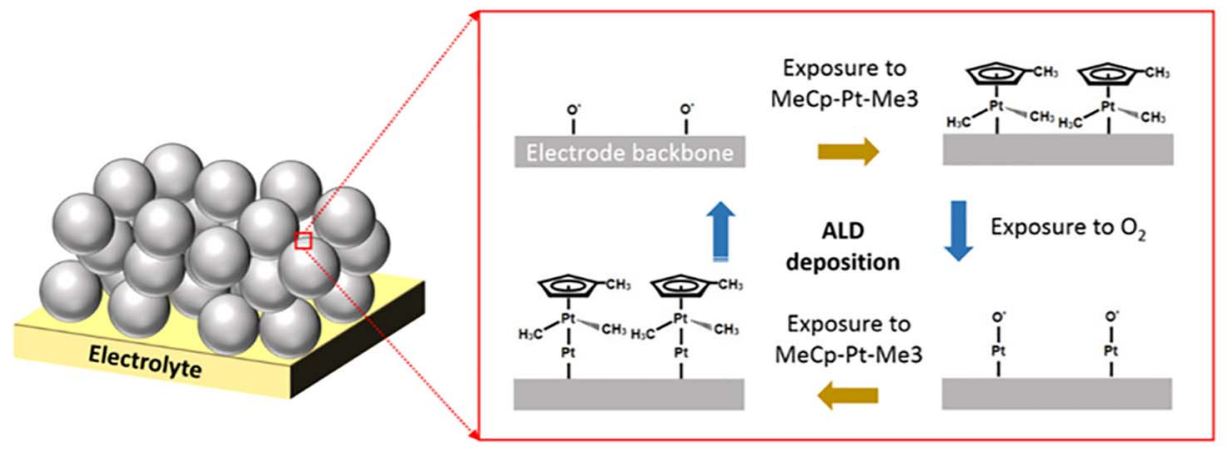

(a)

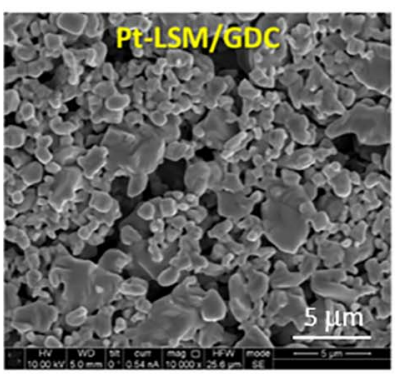

(b)

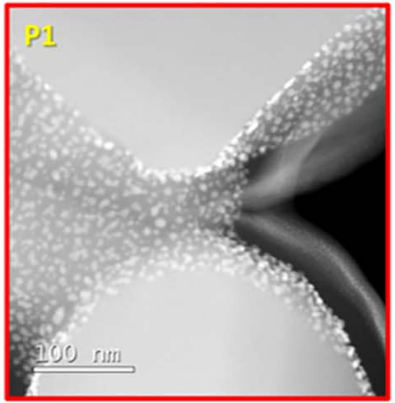

(e)

Average particle size $=6.4 \mathrm{~nm}$ Standard deviation $=1.5 \mathrm{~nm}$

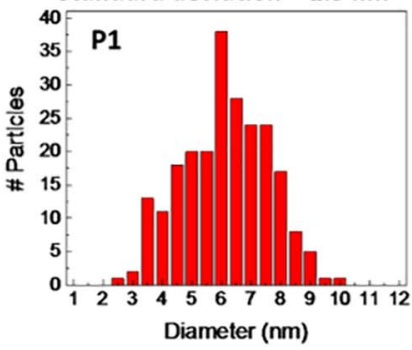

(h)

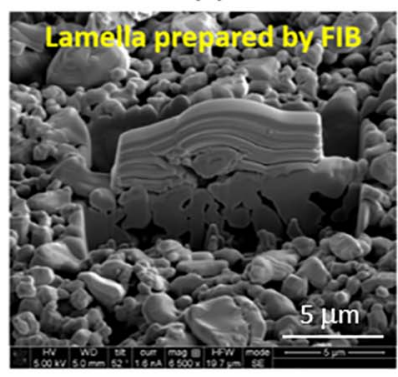

(c)

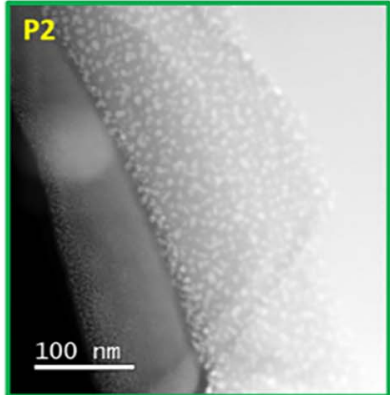

(f)

Average particle size $=7.3 \mathrm{~nm}$ Standard deviation $=1.4 \mathrm{~nm}$

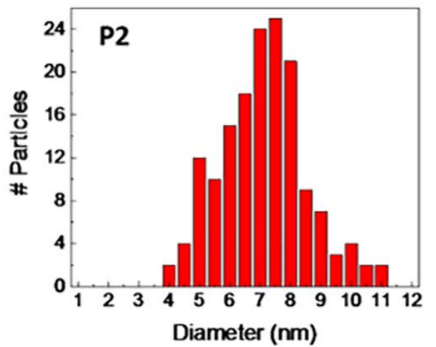

(i)

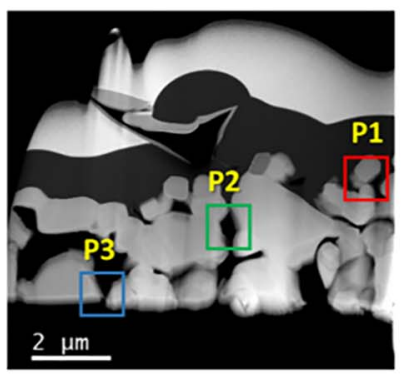

(d)

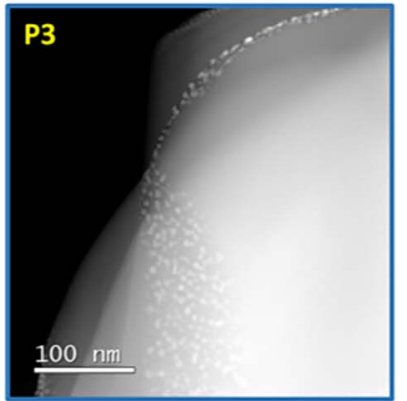

(g)

Average particle size $=6.5 \mathrm{~nm}$ Standard deviation $=1.6 \mathrm{~nm}$

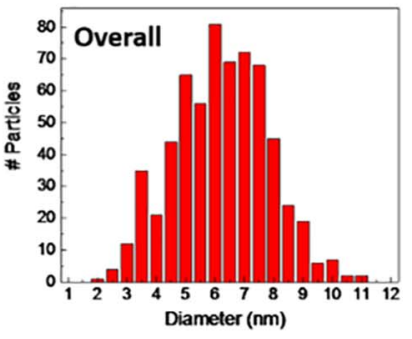

(j)
Fig. 1. (a) Schematic representation of Pt deposition on the porous LSM/GDC electrode backbone using ALD. (b) and (c) SEM images of the surface of the Pt-loaded LSM/GDC, displaying the location of the cross-section. (d) HAADFSTEM image of the TEM lamella. The sample is covered by a stack of protective $\mathrm{SiO}_{2}$ /Pt layers. (e), (f) and (g) HAADF-STEM images of the Ptloaded LSM/GDC at three different points of interest. (h), (i) and (j) show the corresponding size distributions at two points and in the overall lamella. was observed. On the other hand, the Pt-loaded LSM/GDC exhibited non-Faradaic behavior under both positive and negative polarizations. For instance, Fig. 2(b) displays the impact of three consecutive steps of small positive currents $(I=300,500$ and $100 \mu \mathrm{A})$ on the catalytic rate of $\mathrm{CO}_{2}$ production at $300{ }^{\circ} \mathrm{C}$. The rate of propane oxidation gradually increases from $2.20 \times 10^{-8} \mathrm{~mol} \mathrm{CO}_{2} \cdot \mathrm{s}^{-1}$ and reaches a steady-state value at $2.88,2.93$ and $2.79 \times 10^{-8} \mathrm{~mol} \mathrm{CO}_{2} \cdot \mathrm{s}^{-1}$, i.e. a rate enhancement of 131,133 and $127 \%(\rho=1.31,1.33$ and 1.27) respectively. The apparent Faradaic efficiency, $\Lambda$, was found to be 14.6, 10.0 and 38.6, respectively, for the three different applied currents. Thus, the catalytic activity is up to 38.6 times higher than that predicted by Faraday's law, considering electro-oxidation of propane with oxygen ions. After interruption of the current the reaction rate returned slowly to its open-circuit value, indicating the reversibility of EPOC.
The increase in the reaction rate observed under positive polarization can be explained on the basis of the rules of electrochemical promotion [29]. It has been established that the supply of an electronegative ion, such as $\mathrm{O}^{2-}$, to the catalyst-electrode surface, weakens the $\mathrm{Pt}-\mathrm{O}$ bonds and therefore increases its work function [1-4]. The latter leads to the improved chemisorption of propane, which is known to be linked with the rate-determining step for propane oxidation $[30,31]$. After current interruption, the $\mathrm{O}^{\delta-}$ promoters are consumed and therefore the catalyst returns to its initial state over time $[29,30]$. The moderate values of the rate enhancement ratio and Faradaic efficiency can be attributed to the pre-activation of the Pt nanoparticles due to their size via self-driven spillover [1-3]. In addition, only a minor part of the current applied between the LSM/GDC electrode and the counter electrode probably passes across the Pt nanoparticles. 

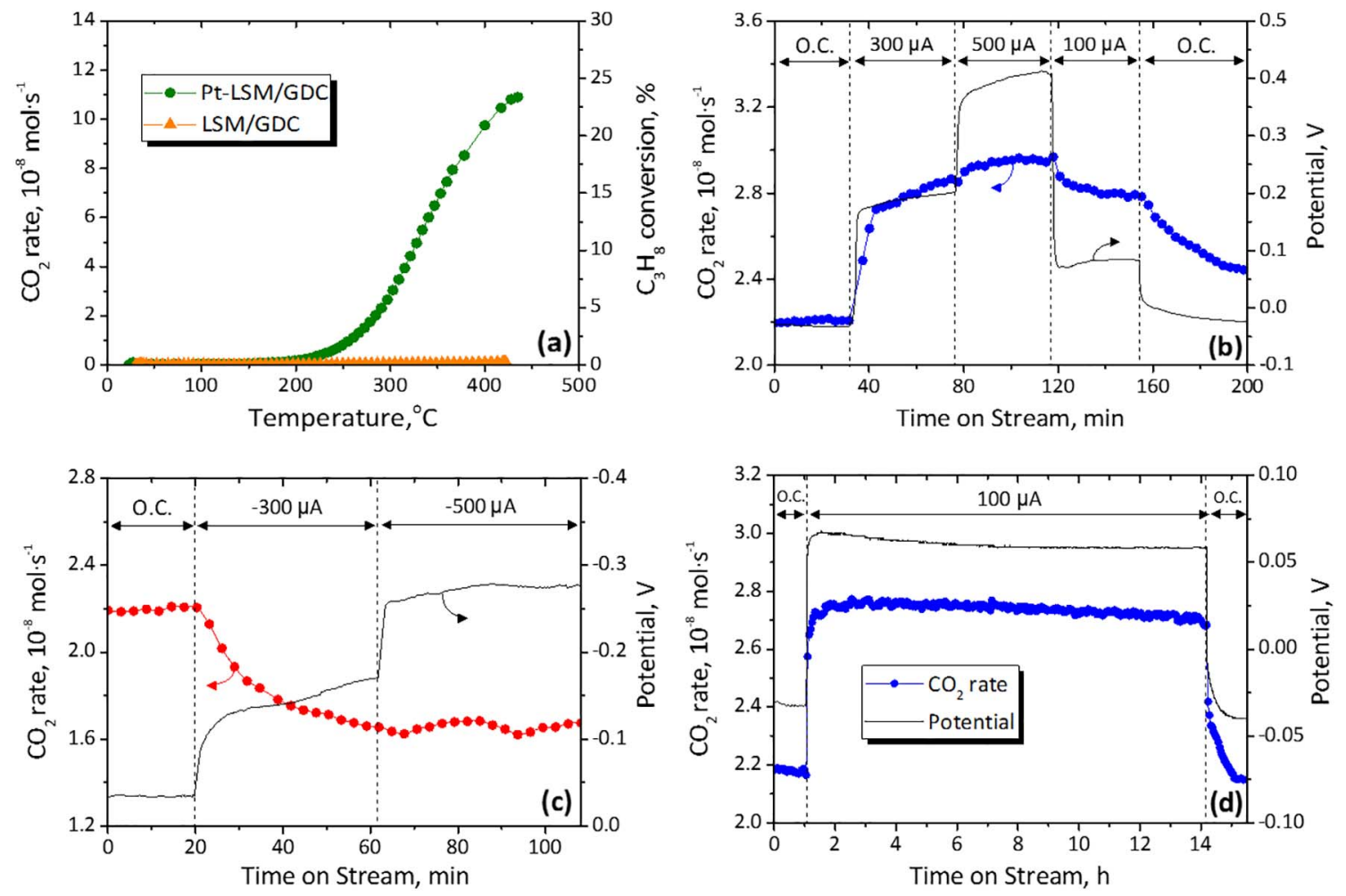

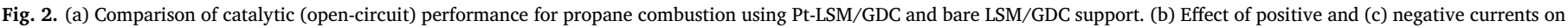
the potential and $\mathrm{CO}_{2}$ formation. (d) EPOC stability test under positive polarization. $P_{\mathrm{C} 3 \mathrm{H} 8} / P_{\mathrm{O} 2}=0.22 \mathrm{kPa} / 2.2 \mathrm{kPa}, T=300{ }^{\circ} \mathrm{C}, F_{\mathrm{t}}=100 \mathrm{ml} \cdot \mathrm{min}{ }^{-1}(\mathrm{NTP})$.

On the other hand, the removal of $\mathrm{O}^{2-}$ from the Pt-loaded sample (negative current application of -300 and $-500 \mu \mathrm{A}$ ) had a poisoning effect on the catalyst, which also resulted in non-Faradaic modification of the catalytic rate (Fig. 2(c)) in good agreement with literature $[10,29]$. Interestingly, the poisoning effect was limited to $74 \%$ of the initial reaction rate and a Faradaic efficiency of 12.0. Application of an even higher negative current $(I=-500 \mu \mathrm{A})$ did not change the catalytic rate; this demonstrates a saturation effect, which can be attributed to the current bypassing the Pt nanoparticles. In other words, the application of a higher negative current cannot affect the performance of the Pt nanoparticles, since the extra current (i.e. oxygen pumping) takes place on Pt-free areas of the LSM/GDC surface.

Finally, the stability of the phenomenon was verified by a long-term experiment applying a current of $100 \mu \mathrm{A}$ (Fig. 2(d)). The performance of the catalyst is relatively steady since the $\mathrm{CO}_{2}$ production rate decreases only slightly from 2.78 to $2.73 \times 10^{-8} \mathrm{~mol} \mathrm{CO}_{2} \cdot \mathrm{s}^{-1}$ after $13 \mathrm{~h}$ of polarization. This indicates that possible agglomeration of Pt nanoparticles during the TPO treatment at a higher temperature (i.e. $425^{\circ} \mathrm{C}$ ) has resulted in a stable catalyst configuration.

\section{Conclusions}

The combination of ALD with SOEC technological advances led to a Pt-decorated composite electrode, which was successfully employed for the electropromotion of propane combustion. In the implemented design, the three functionalities (i.e. catalytic activity, electronic and ionic conductivity) needed for efficient EPOC catalysts are separated into three phases (i.e. Pt, LSM and GDC). The moderate magnitude of electrochemical promotion can be attributed to the pre-activation of the Pt nanoparticles due to their small size via self-driven spillover or current by-pass. Future plans aimed at enhancing the magnitude of the effect will be directed towards tuning either the Pt loading and/or the electronic conductivity of the electrode backbone.

Utilization of the ALD technique brings EPOC systems one step closer to commercialization due to minimized catalyst loadings. In view of the possible practical application of EPOC, the success of our concept should be verified with reactions of industrial importance, where modifications in product selectivity can also occur.

\section{Acknowledgements}

The authors acknowledge the NWO (NCI-CHIPP.2015.001) programme for partial financial support, B. Barcones for FIB preparation of the TEM sample, Solliance and the Dutch province of Noord-Brabant for funding the TEM facility, doctoral mobility grants (Avenir Lyon SaintEtienne Program) and iMUST mobility program from Université de Lyon.

\section{References}

[1] C.G. Vayenas, S. Bebelis, C. Pliangos, S. Brosda, D. Tsiplakides, Electrochemical Activation of Catalysis: Promotion, Electrochemical Promotion and Metal-support Interactions, Kluwer Academic/Plenum, New York, 2001.

[2] P. Vernoux, L. Lizarraga, M.N. Tsampas, F.M. Sapountzi, A. De Lucas-Consuegra, J.L. Valverde, S. Souentie, C.G. Vayenas, D. Tsiplakides, S. Balomenou, E.A. Baranova, Ionically conducting ceramics as active catalytic supports, Chem. Rev. 113 (2013) 8192-8260.

[3] M.N. Tsampas, F.M. Sapountzi, P. Vernoux, Applications of yttria stabilized zirconia (YSZ) in catalysis, Cat. Sci. Technol. 5 (2015) 4884-4900.

[4] I. Garagounis, V. Kyriakou, C. Anagnostou, V. Bourganis, I. Papachristou, M. Stoukides, Solid electrolytes: applications in heterogeneous catalysis and chemical cogeneration, Ind. Eng. Chem. Res. 50 (2011) 431-472.

[5] M. Stoukides, C.G. Vayenas, The effect of electrochemical oxygen pumping on the rate and selectivity of ethylene oxidation on polycrystalline silver, J. Catal. 70 (1981) 137-146.

[6] M.N. Tsampas, A. Kambolis, E. Obeid, L. Lizzaraga, F. Sapountzi, P. Vernoux, Electrochemical promotion of propane oxidation on Pt deposited on a dense $\beta^{\prime \prime}$ $\mathrm{Al}_{2} \mathrm{O}_{3}$ ceramic Ag ${ }^{+}$conductor, Front. Chem. 1 (2013) 13.

[7] S. Balomenou, D. Tsiplakides, A. Katsaounis, S. Thiemann-Handler, B. Cramer, G. Foti, Ch. Comninellis, C.G. Vayenas, Novel monolithic electrochemically promoted catalytic reactor for environmentally important reactions, Appl. Catal., B 52 (2004) 181-196.

[8] C. Xia, M. Hugentobler, Y. Li, C. Comninellis, W. Harbich, Quantifying electrochemical promotion of induced bipolar Pt particles supported on YSZ, Electrochem. Commun. 12 (2010) 1551-1554.

[9] D. Poulidi, M.E. Rivas, I.S. Metcalfe, Controlled spillover in a single catalyst pellet: 
rate modification, mechanism and relationship with electrochemical promotion, J. Catal. 281 (2011) 188-197.

[10] A. Kambolis, L. Lizarraga, M.N. Tsampas, L. Burel, M. Rieu, J.-P. Viricelle, P. Vernoux, Electrochemical promotion of catalysis with highly dispersed Pt, Electrochem. Commun. 19 (2012) 5-8.

[11] J. González-Cobos, D. Horwat, J. Ghanbaja, J.L. Valverde, A. de Lucas-Consuegra, Electrochemical activation of Au nanoparticles for the selective partial oxidation of methanol, J. Catal. 317 (2014) 293-302.

[12] H.A.E. Dole, L.F. Safady, S. Ntais, M. Couillard, E.A. Baranova, Electrochemically enhanced metal-support interaction of highly dispersed Ru nanoparticles with a $\mathrm{CeO}_{2}$ support, J. Catal. 318 (2014) 85-94.

[13] Y.M. Hajar, K.D. Patel, U. Tariq, E.A. Baranova, Functional similarity of electrochemical promotion and metal support interaction for $\mathrm{Pt}$ and $\mathrm{RuO}_{2}$ nanoparticles, J. Catal. 352 (2017) 42-51.

[14] E. Ruiz, D. Cillero, P.J. Martínez, A. Morales, G. San Vicente, G. de Diego, J.M. Sánchez, Electrochemical synthesis of fuels by $\mathrm{CO}_{2}$ hydrogenation on $\mathrm{Cu}$ in a potassium ion conducting membrane reactor at bench scale, Catal. Today 236 (2014) 108-120.

[15] A. de Lucas-Consuegra, J. González-Cobos, V. Carcelén, C. Magén, J.L. Endrino J.L. Valverde, Electrochemical promotion of Pt nanoparticles dispersed on a diamond-like carbon matrix. A novel electrocatalytic system for $\mathrm{H}_{2}$ production, J. Catal. 307 (2013) 18-26.

[16] J. González-Cobos, E. Ruiz-López, J.L. Valverde, A. de Lucas-Consuegra, Electrochemical promotion of a dispersed $\mathrm{Ni}$ catalyst for $\mathrm{H}_{2}$ production via partial oxidation of methanol, Int. J. Hydrog. Energy 41 (2016) 19418-19429.

[17] V. Roche, R. Revel, P. Vernoux, Electrochemical promotion of YSZ monolith honeycomb for deep oxidation of methane, Catal. Commun. 11 (2010) 1076-1080.

[18] J.T.S. Irvine, D. Neagu, M.C. Verbraeken, C. Chatzichristodoulou, C. Graves, M.B. Mogensen, Evolution of the electrochemical interface in high-temperature fuel cells and electrolysers, Nat. Energy 1 (2016) 15014.

[19] X.A. Xi, A. Kondo, T. Kozawa, M. Naito, LSCF-GDC composite particles for solid oxide fuel cells cathodes prepared by facile mechanical method, Adv. Powder Technol. 27 (2016) 646-651.
[20] S.M. George, Atomic layer deposition: an overview, Chem. Rev, 110 (2010) $111-131$

[21] C. Detavernier, J. Dendooven, S.P. Sree, K.F. Ludwig, J.A. Martens, Tailoring nanoporous materials by atomic layer deposition, Chem. Soc. Rev. 40 (2011) 5242-5253.

[22] A.J.M. Mackus, M.J. Weber, N.F.W. Thissen, D. Garcia-Alonso, R.H.J. Vervuurt, S. Assali, A.A. Bol, M.A. Verheijen, W.M.M. Kessels, Atomic layer deposition of Pd and Pt nanoparticles for catalysis: on the mechanisms of nanoparticle formation, Nanotechnology 27 (2016) 034001.

[23] J. Lu, J.W. Elam, P.C. Stair, Synthesis and stabilization of supported metal catalysts by atomic layer deposition, Acc. Chem. Res. 46 (2013) 1806-1815.

[24] H.C.M. Knoops, A.J.M. Mackus, M.E. Donder, M.C.M. van de Sanden, P.H.L. Notten, W.M.M. Kessels, ALD of platinum and platinum oxide films, Electrochem. SolidState Lett. 12 (2009) G34-G36.

[25] C. Marichy, M. Bechelany, N. Pinna, Atomic layer deposition of nanostructured materials for energy and environmental applications, Adv. Mater. 24 (2012) 1017-1032.

[26] B.J. O'Neill, D.H.K. Jackson, J. Lee, C. Canlas, P.C. Stair, C.L. Marshall, J.W. Elam, T.F. Kuech, J.A. Dumesic, G.W. Huber, Catalyst design with atomic layer deposition, ACS Catal. 5 (2015) 1804-1825.

[27] A. Borodzinski, M. Bonarowska, Relation between crystallite size and dispersion on supported metal catalysts, Langmuir 13 (1997) 5613-5620.

[28] J. Yang, V. Tschamber, D. Habermacher, F. Garin, P. Gilot, Effect of sintering on the catalytic activity of a Pt based catalyst for $\mathrm{CO}$ oxidation: experiments and modeling, Appl. Catal., B 83 (2008) 229-239.

[29] C.G. Vayenas, S. Brosda, Electron donation-backdonation and the rules of catalytic promotion, Top. Catal. 57 (2014) 1287-1301.

[30] M.N. Tsampas, F.M. Sapountzi, A. Boréave, P. Vernoux, Isotopical labeling mechanistic studies of electrochemical promotion of propane combustion on Pt/YSZ, Electrochem. Commun. 26 (2013) 13-16.

[31] L. Lizarraga, M. Guth, A. Billard, P. Vernoux, Electrochemical catalysis for propane combustion using nanometric sputtered-deposited Pt films, Catal. Today 157 (2010) $61-65$ 